\title{
Control of Exocytosis from Adrenal Chromaffin Cells
}

\author{
Ronald W. Holz ${ }^{1}$ \\ Received October 10, 1987; accepted November 30, 1987 \\ KEY WORDS: exocytosis; catecholamine; adrenal chromaffin cell; $\mathrm{Ca}^{2+}$; protein kinase; digitonin.
}

\section{SUMMARY}

1. Calcium-dependent exocytosis of catecholamines from intact and digitonin-permeabilized bovine adrenal chromaffin cells was investigated.

2. ${ }^{45} \mathrm{Ca}^{2+}$ uptake and secretion induced by nicotinic stimulation or depolarization in intact cells were closely correlated. The results provide strong support for $\mathrm{Ca}^{2+}$ entry being the trigger for exocytosis.

3. Experiments in which the $\mathbf{H}^{+}$electrochemical gradient across the intracellular secretory granule (chromaffin granule) membrane was altered indicated that the gradient does not play an important role in exocytosis.

4. $\mathrm{Ca}^{2+}$ entry into the cells is associated with activation of phospholiphase $\mathrm{C}$ and a rapid translocation of protein kinase $C$ to membranes.

5. The plasma membrane of chromaffin cells was rendered permeable to $\mathrm{Ca}^{2+}$, ATP, and proteins by the detergent digitonin without disruption of the intracellular secretory granules. In this system in which the intracellular milieu can be controlled, micromolar $\mathrm{Ca}^{2+}$ directly stimulated catecholamine secretion.

6. Treatment of the cells with phorbol esters and diglyceride, which activate protein kinase $\mathrm{C}$, enhanced phosphorylation and subsequent $\mathrm{Ca}^{2+}$-dependent secretion in digitonin-treated cells.

7. Phorbol ester-induced secretion could be specifically inhibited by trypsin. The experiments indicate that protein kinase $\mathrm{C}$ modulates but is not necessary for $\mathrm{Ca}^{2+}$-dependent secretion.

\footnotetext{
${ }^{1}$ Department of Pharmacology, University of Michigan, Ann Arbor, Michigan 48109.
} 


\section{INTRODUCTION}

Secretion of prepackaged hormones and neurotransmitfers generally occurs by exocytosis. Although exocytosis has been extensively studied, little is known about the physiological and biochemical mechanisms underlying it. Studies on the perfused adrenal medulla and adrenal medullary slices helped define the process and demonstrated that in this tissue $\mathrm{Ca}^{2+}$ influx initiates secretion (Douglas, 1975; Viveros, 1975). Acetylcholine released from cholinergic nerves interacts with receptors on chromaffin cells to cause $\mathrm{Ca}^{2+}$ entry. In the bovine adrenal medulla nicotinic but not muscarinic receptor activation is responsible for these events. Although studies with the perfused gland and adrenal medullary slices led to a greatly increased understanding of secretion and served as a model for studies in other secretory systems, they were often limited in time resolution and in the ability to investigate biochemical events associated with secretion. These limitations have been overcome by the development of techniques to dissociate large numbers of bovine adrenal chromaffin cells and to study secretion either from suspended from cells or from monolayer cultures. The following is a brief description of some of the studies we have undertaken in monolayer cultures and with suspended chromaffin cells to elucidate further those factors which control and underlie exocytosis.

\section{METHODS}

Primary dissociated cells from bovine adrenal medulla were prepared and maintained as monolayer cultures or as suspended cells as previously described (Holz et al., 1982, 1983). Experiments with intact cells were generally performed at $25^{\circ} \mathrm{C}$ in a physiological salt solution (PSS) containing $142 \mathrm{mM} \mathrm{NaCl}, 5.6 \mathrm{mM}$ $\mathrm{KCl}, 2.2 \mathrm{~m} M \mathrm{CaCl}_{2}, 0.5 \mathrm{~m} M \mathrm{MgCl}_{2}, 15 \mathrm{~m} M$ Hepes (pH 7.4), $5.6 \mathrm{~m} M$ glucose, and $0.5 \mathrm{~m} M$ ascorbate. Catecholamine secretion and ${ }^{45} \mathrm{Ca}^{2+}$ uptake were measured as previously described (Holz et al., 1982). Experiments with digitonintreated cells were usually performed in a solution containing $145 \mathrm{mM}$ potassium glutamate, $5 \mathrm{mM}$, various concentrations of calcium, 1-5 $\mathrm{mM} \mathrm{MgATP}$, and $20 \mathrm{~m} M$ Pipes (pH 6.60) (Dunn and Holz, 1983). The free $\mathrm{Ca}^{2+}$ concentration was calculated according to Portzehl et al. (1964). Catecholamine secretion was measured by determining the fractional release from cells of endogenous catecholamine or of $\left[{ }^{3} \mathrm{H}\right]$ norepinephrine in cells which had been preincubated with $\left[{ }^{3} \mathrm{H}\right]$ norepinephrine to label intracellular catecholamine stores.

\section{RESULTS AND DISCUSSION}

Relationship Between ${ }^{45} \mathrm{Ca}^{2+}$ Uptake and Catecholamine Secretion. Douglas and co-workers demonstrated that extracellular $\mathrm{Ca}^{2+}$ is required for secretion from perfused adrenal medulla and that ${ }^{45} \mathrm{Ca}^{2+}$ uptake into the gland was associated with secretion (Douglas, 1975). In monolayer cultures the relationship between calcium uptake and secretion could be determined more precisely 
(Kilpartick et al., 1982; Holz et al., 1982). The rate of catecholamine secretion induced by the mixed nicotinic-muscarinic agonist carbachol was maximal during the initial 2 min and slowed thereafter (Fig. 1). Significant carbachol-stimulated $\mathrm{Ca}^{2+}$ uptake could be detected at $15 \mathrm{sec}$ before the occurrence of significant catecholamine secretion. The rate of carbachol-induced $\mathrm{Ca}^{2+}$ uptake was maximal between 0 and $1 \mathrm{~min}$ and significantly slowed after $5 \mathrm{~min}$. Both catecholamine secretion and ${ }^{45} \mathrm{Ca}^{2+}$ uptake were stimulated by selective nicotinic agonists (nicotine, 1,1-dimethyl-4-phenylpiperazinium) and by mixed nicotinic-muscarinic agonists (acetylcholine and carbachol) but not by selective muscarinic agonists (muscarine, methacholine) (Holz et al., 1982). Similarly, nicotinic but not muscarinic antagonists blocked carbachol-induced secretion and ${ }^{45} \mathrm{Ca}^{2+}$ uptake (Holz et al., 1982). Thus, nicotinic receptor activation is responsible for both increased calcium permeability and increased catecholamine secretion.

Secretion and calcium uptake were also stimulated by depolarization induced by elevated $\mathrm{K}^{+}$. Calcium probably entered the cell through voltage-sensitive calcium channels. Again, there was a close temporal relationship between calcium uptake and catecholamine secretion.

The studies strongly support the conclusion from the now-classical work of Douglas and co-workers (Douglas, 1975) that $\mathrm{Ca}^{2+}$ entry initiates and maintains secretion from adrenal medullary cells.

Absence of a Role in Exocytosis for the $\mathrm{H}^{+}$Electrochemical Gradient Across the Secretory Granule Membrane. A common feature of secretory granules is their low internal $\mathrm{pH}$ and a membrane-bound electrogenic $\mathrm{H}^{+}$translocating ATPase (Njus et al. 1986). The most extensively studied secretory granule, the chromaffin granule from adrenal chromaffin cells, has a $\mathrm{pH}$ of approximately 5.6 in vitro and an electrogenic $\mathrm{H}^{+}$translocating ATPase that generates a $\mathrm{H}^{+}$ electrochemical gradient across the granule membrane of over $120 \mathrm{mV}$ (Johnson and Scarpa, 1976; Casey et al., 1977; Holz, 1978; Njus et al.,1986). Catecholamine uptake into chromaffin granules is coupled to the $\mathrm{H}^{+}$electrochemical gradient. The common occurrence of $\mathrm{H}^{+}$electrochemical gradients across membranes of a wide variety of secretory granules raised the possibility that the $\mathrm{H}^{+}$electrochemical potential of granules may, in addition, be important for exocytosis. However, studies using a variety of different manipulations indicated that the $\mathrm{H}^{+}$electrochemical gradient across the granule membrane is probably not involved in exocytosis (Holz et al., 1983). An important aspect of these studies was the use of techniques to assess the effects of various manipulations on the $\mathrm{H}^{+}$electrochemical gradient of chromaffin granules within cells. Weak bases such as methylamine (Johnson and Scarpa, 1979) or ammonium or the ionophore nigericin (Johnson and Scarpa, 1976), which exchanges protons and alkali metal ions across membranes, partially collapsed the $\mathrm{pH}$ gradient across chromaffin granule membranes in vitro. We determined, using ${ }^{31} \mathrm{P} \mathrm{nmr}$ of ATP within intracellular chromaffin granules and radiometric techniques based upon the uptake of radioactive methylamine, that $20-30 \mathrm{~m} M$ methylamine or ammonium or $1 \mu M$ nigericin shifted the $\mathrm{pH}$ within intracellular chromaffin granules from 5.3 to 6.3 (Holz et al., 1983). Under these conditions catecholamine secretion was not inhibited. 

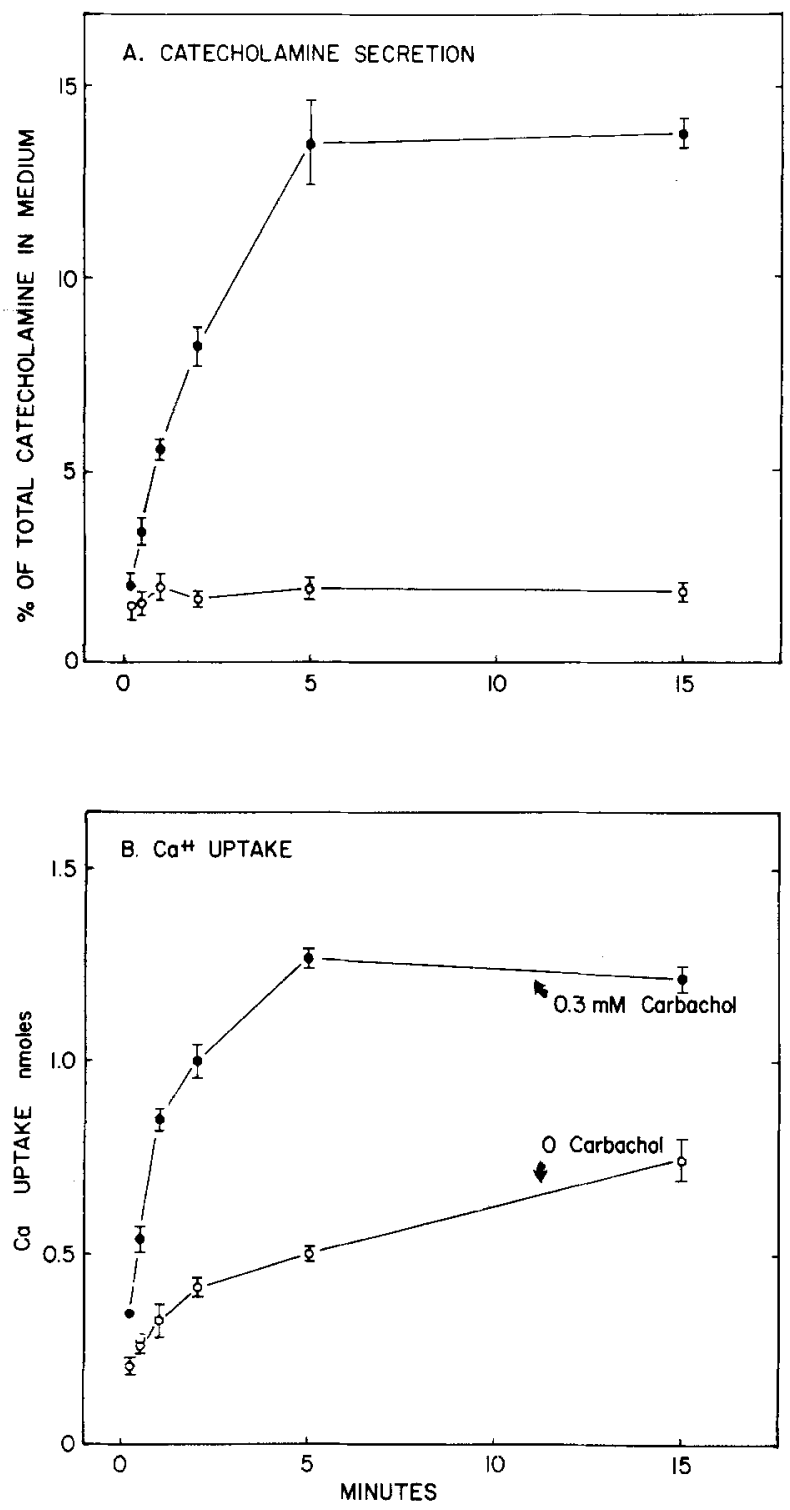

Fig. 1. Time course of carbachol-induced catecholamine secretion (A) and $\mathrm{Ca}^{2+}$ uptake (B). Cells were incubated in a solution containing ${ }^{45} \mathrm{Ca}^{2+}$ in the presence $(O)$ or absence $(O)$ of $0.3 \mathrm{mM}$ carbachol. The solution was aspirated at various times and saved for measurement of catecholamine release from the cells. There were four wells per group. (From Holz et al., 1982.) 
Another approach involved the use of dicyclohexylcarbodiimide (DCCD), an irreversible inhibitor of $\mathrm{H}^{+}$translocating ATPases. Under conditions in which the $\mathrm{H}^{+}$translocating ATPase of chromaffin granules within cells was inhibited, there was no effect on elevated $\mathrm{K}^{+}$-induced secretion. Similarly, FCCP, a $\mathrm{H}^{+}$ ionophore, which reduces the granule membrane potential to the $\mathrm{H}^{+}$equilibrium potential in isolated chromaffin granules (and, thereby, reduces to zero the $\mathbf{H}^{+}$ electrochemical gradient) had no effect or caused a small enhancement of secretion induced by nicotinic stimulation at concentrations which maximally uncoupled mitochondria within chromaffin cells (Holz et al., 1983).

These experiments indicate that secretion does not require (1) the complete $\mathrm{H}^{+}$concentration gradient across the granule membrane, (2) a normal $\mathrm{H}^{+}$ electrochemical gradient across the granule membrane, (3) an inside positive granule electrical potential, or (4) an active granule membrane $\mathrm{H}^{+}$pump ATPase.

Secretion from Chromaffin Cells with Plasma Membranes Rendered Leaky by Digitonin. One of the major limitations in the study of a complex cellular process such as exocytosis is the inability to control the intracellular milieu. Knight and Baker (1982) permeabilized the plasma membrane of freshly suspended adrenal medullary cells by exposing cell suspensions to high-voltage discharges which caused localized dielectric breakdown of the plasma membrane. They found that micromolar $\mathrm{Ca}^{2+}$ without secretagogue induced exocytosis. We have permeabilized monolayer chromaffin cells with the detergent digitonin, which interacts with cholesterol in membranes (Dunn and Holz, 1983). Although digitonin at high concentrations can completely disrupt cells, we found that exposure of cells to low concentrations of digitonin $(10$ to $20 \mu M)$ for short times (less than $15 \mathrm{~min}$ ) caused the cells to become permeable to low molecular weight ions such as $\mathrm{Ca}^{2+}$ and ATP, to carbohydrates as large as the tetrasaccharide stachyose, and to lactate dehydrogenase, a cytosolic protein marker, which exited from the cells with a half-time of 10-15 min. Intracellular chromaffin granules, however, remained intact, did not leak catecholamines, and were able to maintain a $\mathrm{H}^{+}$electrochemical gradient (Holz and Senter, 1985). Most importantly, at these low concentrations of digitonin, micromolar $\mathrm{Ca}^{2+}$ stimulated catecholamine release (Fig. 2). Similar results were obtained by Wilson and Kirshner (1983). Figure 3 demonstrates that the cells were responsive to calcium from below 1 to $10 \mu M$. The response to $\mathrm{Ca}^{2+}$ was specific since the $1 \mathrm{~m} M$ free $\mathrm{Mg}^{2+}$ which was presented in the solutions did not support catecholamine release. The $\mathrm{Ca}^{2+}$ concentrations are within the physiological range which stimulates intracellular events in intact cells and are approximately $1 / 500$ th of that necessary to support secretagogue-induced secretion from intact cells (Fig. 3).

If cells are permeabilized for $10 \mathrm{~min}$ in the absence of ATP to deplete the cytosol of ATP, subsequent addition of ATP in the presence and absence of $\mathrm{Ca}^{2+}$ indicates that at least $75 \%$ of the $\mathrm{Ca}^{2+}$-dependent secretion is also ATP dependent. The results suggest that ATP plays a direct role in the secretory process. Baker and Knight (1982), using cells permeabilized by intense electric fields, arrived at the same conclusion. 

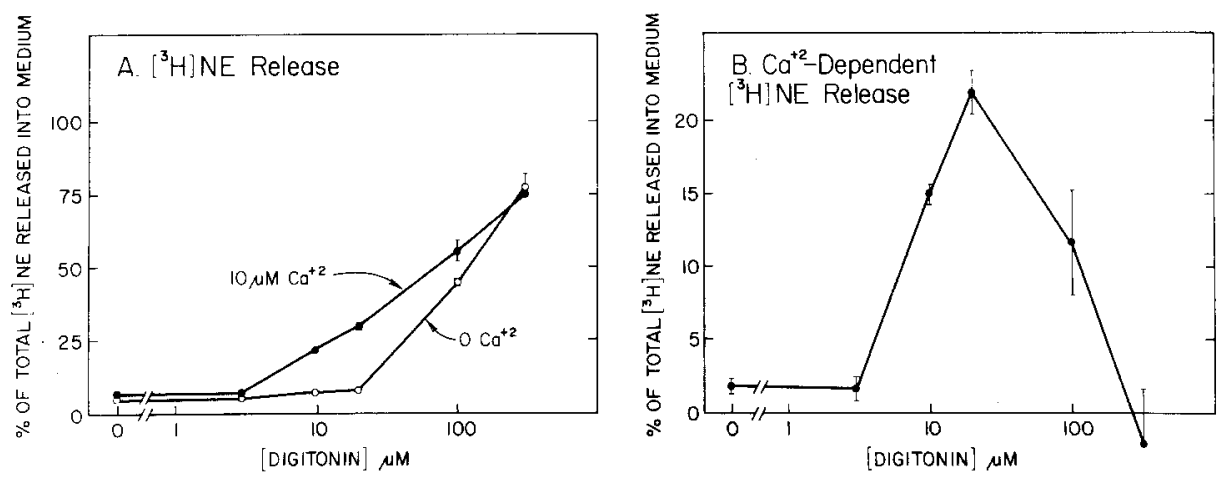

Fig. 2. Effect of various concentrations of digitonin on norepinephrine release from chromaffin cells. Cells containing $\left[{ }^{3} \mathrm{H}\right]$ norepinephrine (NE) were incubated in potassium glutamate solutions containing $5 \mathrm{mM} \mathrm{MgATP}$ and various concentrations of digitonin in the presence or absence of $10 \mu M \mathrm{Ca}^{2+}$. After $15 \mathrm{~min}$, the solution was removed, and $\left[{ }^{3} \mathrm{H}\right]$ norepinephrine released in the $\left[{ }^{3} \mathrm{H}\right]$ norepinephrine solution and that remaining in the cells were measured. (A) $\left[{ }^{3} \mathrm{H}\right]$ Norepinephrine released into the medium in the presence and absence of $10 \mu \mathrm{M} \mathrm{Ca}{ }^{2+}$; (B) difference between release of $\left[{ }^{3} \mathrm{H}\right]$ norepinephrine in the presence and that in the absence of $\mathrm{Ca}^{2+}$. There were three wells per group. (From Dunn and Holz, 1983.)

Phorbol Esters Stimulate Protein Phosphorylation and Secretion. Protein kinase $\mathrm{C}$ is $\mathrm{Ca}^{2+}$ dependent and requires acidic phospholipids for maximal activity (Wise et al., 1982; Kikkawa et al., 1982). Diglyceride in the presence of phosphatidylserine increases the calcium sensitivity of the enzyme to micromolar concentrations (Kishimoto et al., 1980). Tumor promoting phorbol esters such as tetradecanoylphorbol 13-acetate (TPA) substitute for diglyceride in vitro to

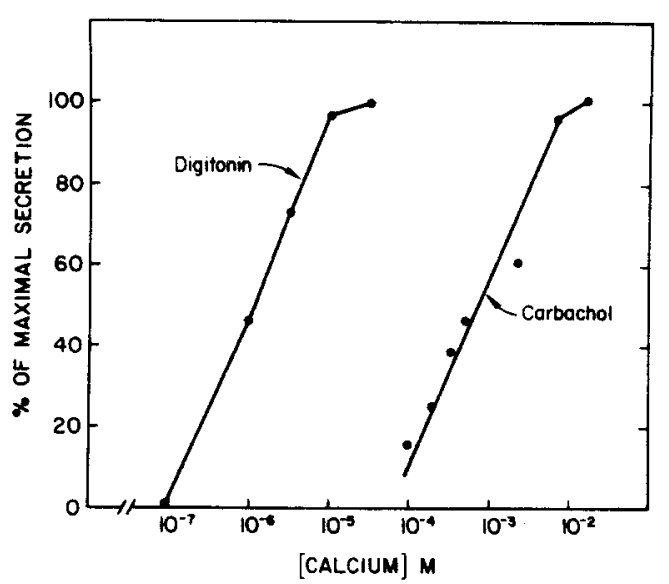

Fig. 3. Effect of various calcium concentrations on secretion in the presence of digitonin or carbachol. $\mathrm{Ca}^{2+}$-dependent $\left[{ }^{3} \mathrm{H}\right]$ norepinephrine release into the medium by digitonin-treated cells was measured in $139 \mathrm{~m} M$ potassium glutamate, $20 \mathrm{~m} M$ Pipes (pH 6.6), $5 \mathrm{~m} M$ MgATP, $5 \mathrm{~m} M$ glucose, $0.5 \mathrm{~m} M$ ascorbic acid, and $20 \mu M$ digitonin after $15 \mathrm{~min}$. Calcium concentrations were buffered with $5 \mathrm{mM}$ EGTA. Carbacholdependent secretion of endogenous catecholamine was measured in $142 \mathrm{mM} \mathrm{NaCl}$, $5.6 \mathrm{~m} M \mathrm{KCl}, \quad 3.6 \mathrm{~m} M \quad \mathrm{NaHCO}_{3}, 0.5 \mathrm{~m} M$ $\mathrm{MgCl}_{2}, 15 \mathrm{mM}$ Na-Hepes (pH 7.4), $5.6 \mathrm{mM}$ glucose, and $0.5 \mathrm{~m} M$ ascorbic acid with various amounts of calcium (in the absence of EGTA) after $2 \mathrm{~min}$. Carbachol concentration was $0.3 \mathrm{~m} M$. Maximal calcium-dependent secretion in the presence of digitonin was $28.5 \%$ of the total $\left[{ }^{3} \mathrm{H}\right]$ norepinephrine. Maximal calcium-dependent secretion in the presence of carbachol was $9.6 \%$ of the total endogenous catecholamine. There were three samples/groups. (From Dunn and Holz, 1983.) 
increase the activity and calcium sensitivity of the enzyme (Castagna et al., 1982). Most imporantly, TPA activates protein kinase $\mathrm{C}$ and protein phosphorylation in intact platelets and enhances serotonin secretion (Castagna et al., 1982; Yamanishi et al., 1983).

The effects of various activators of protein kinase $C$ (phorbol esters and dioctanoylglycerol, $\mathrm{DiC}_{8}$ ) on secretion and protein phosphorylation were investigated in intact and digitonin-permeabilized cells. Protein phosphorylation was measured using one- and two-dimensional electrophoresis and autoradiography of ${ }^{32} \mathrm{P}$-labeled proteins. Because activation of protein kinase $\mathrm{C}$ is associated with translocation of the enzyme from cytosol to membranes, changes in the subcellular localization of protein kinase $\mathrm{C}$ in response to phorbol esters, $\mathrm{DiC}_{8}$, nicotinic agonists, and muscarinic agonists were also investigated.

TPA induced a dose-dependent increase in catecholamine release from intact chromaffin cells which occurred gradually over a period of $2 \mathrm{hr}$ (Pocotte et al., 1985; M. A. Bittner and R. W. Holz, unpublished observations). The release at 90 min was approximately $10 \%$ of the total catecholamine and contrasts with the rapid release induced by nicotinic agonists or by depolarization of 15-20\% of the total catecholamine in 5-10 min. TPA-induced catecholamine release was associated with a proportional release of soluble dopamine- $\beta$-hydroxylase (M. A. Bittner and R. W. Holz, unpublished observations), a soluble protein marker for the chromaffin granule interior. Thus, the release was exocytotic.

TPA and other phorbol esters which activate protein kinase $\mathrm{C}$ also potentiate secretion induced from intact cells by $\mathrm{Ba}^{2+}$ and $\mathrm{Ca}^{2+}$ ionophore in the presence of $\mathrm{Ca}^{2+}$ (Pocotte et al., 1985). Phorbol esters also enhance catecholamine secretion induced by nicotinic agonists (TerBush, Bittner and Holz, manuscript in preparation). We have recently found that within $2 \mathrm{sec}$ the nicotinic agonist DMPP (1,1-dimethyl-4-phenylpiperazinium) causes a $\mathrm{Ca}^{2+}$-dependent translocation of $5-10 \%$ of the total cellular potein kinase $\mathrm{C}$ to the membrane (TerBush and Holz, 1986; D. R. TerBush, M. A. Bittner, and R. W. Holz, manuscript in preparation). Associated with the translocation of protein kinase $C$ is a DMPP-induced, $\mathrm{Ca}^{2+}$-dependent activation of phospholipase $\mathrm{C}$ measured by the release of $\left[{ }^{3} \mathbf{H}\right]$ inositol phosphates from cells prelabeled with $\left[{ }^{3} \mathrm{H}\right]$ inositol (Eberhard et al., 1987). Thus, it is likely that nicotinic receptor activation results in $\mathrm{Ca}^{2+}$ influx and a rise in cytosolic $\mathrm{Ca}^{2+}$, which activates phospholipase $\mathrm{C}$. Elevated cytosolic $\mathrm{Ca}^{2+}$ together with a possible increase in diglyceride (or basal levels of diglyceride) cause translocation of protein kinase $C$ to the membrane with subsequent effects on secretion.

The effects of activated protein kinase $\mathrm{C}$ on $\mathrm{Ca}^{2+}$-dependent secretion were directly studied in digitonin-permeabilized chromaffin cells. Cells were incubated with TPA or dioctanoylglycerol $\left(\mathrm{DiC}_{8}\right)$ prior to permeabilization to cause translocation of protein kinase $C$ to membranes (TerBush and Holz, 1986) and activation of the enzyme (Pocotte et al., 1985; Lee and Holz, 1986). Upon permeabilization, $\mathrm{Ca}^{2+}$-induced secretion was enhanced in cells preincubated with TPA (Fig. 4). A similar effect of TPA on $\mathrm{Ca}^{2+}$-dependent secretion had been obtained in suspended chromaffin cells permeabilized by intense electric fields (Knight and Baker, 1983). TPA increased both the sensitivity of the secretory 
system to $\mathrm{Ca}^{2+}$ and the maximal response to $\mathrm{Ca}^{2+}$. Recent studies indicate that translocation of as little as $2 \%$ of the total cellular protein kinase $\mathrm{C}$ to membranes resulted in greater than a $25 \%$ increase in secretion induced by $1 \mu \mathrm{MCa}^{2+}(\mathrm{D} . \mathrm{R}$. TerBush, M. A. Bittner, and R. W. Holz, manuscript in preparation). Thus, the translocation of $5-10 \%$ of the protein kinase $C$ to membranes during nicotinic stimulation of intact cells probably enhances the secretory response to the rise in cytosolic $\mathrm{Ca}^{2+}$.

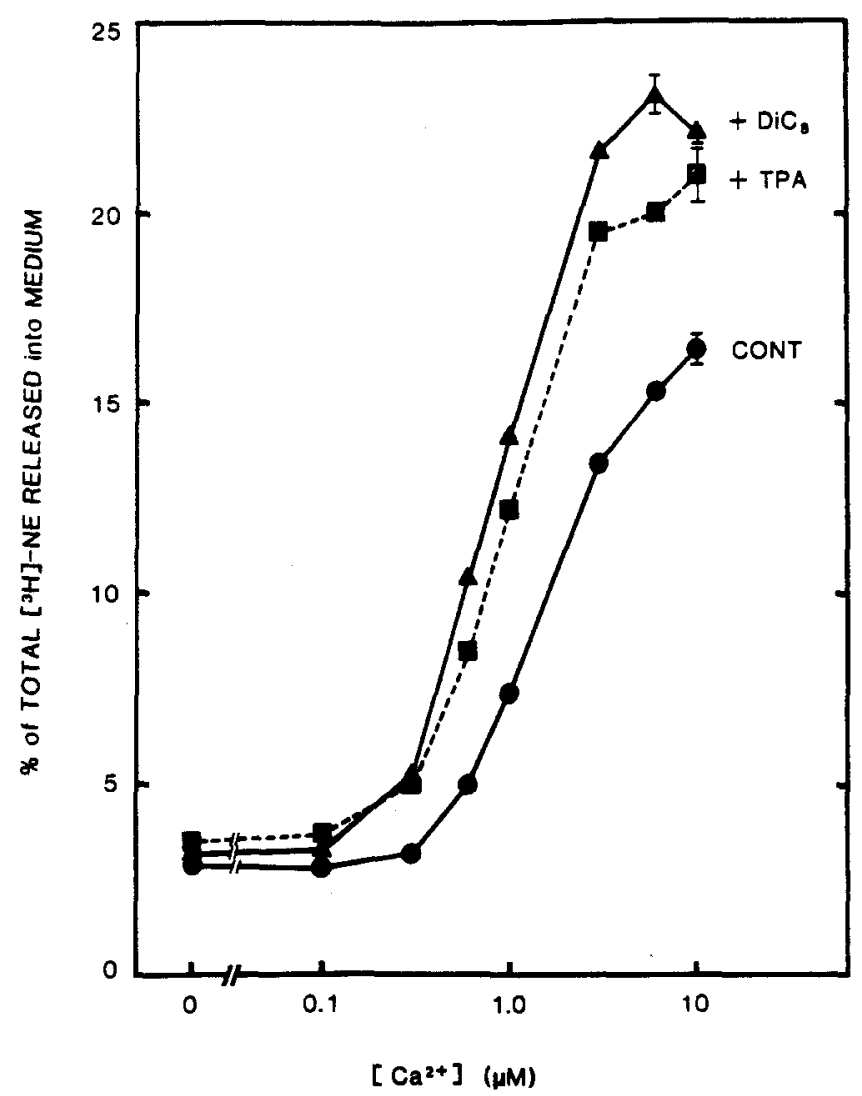

Fig. 4. Effects of dioctanoylglycerol $\left(\mathrm{DiC}_{8}\right)$ and TPA on catecholamine secretion from digitonin-treated chromaffin cells. Chromaffin cells prelabeled with $\left[{ }^{3} \mathrm{H}\right]$ norepinephrine $\left(\left[{ }^{3} \mathrm{H}\right] \mathrm{NE}\right)$ were incubated for $30 \mathrm{~min}$ in PSS containing $100 \mu M \mathrm{DiC}_{8}, 100 \mathrm{n} M$ TPA, or no drug and subsequently stimulated to secrete in KGEP solutions containing $20 \mu M$ digitonin, $10 \mu M \mathrm{MgATP}, 1 \mathrm{~m} M \mathrm{MgCl}_{2}$, various concentrations of $\mathrm{Ca}^{2+}$, and $100 \mu M \mathrm{DiC}_{8}, 100 \mathrm{n} M \mathrm{TPA}$, or vehicle. The percentage of $\left[{ }^{3} \mathrm{H}\right]$ norepinephrine released into the medium was determined after 6 min. Each group contained three wells. Endogenous intracellular ATP was not allowed to exit before the addition of $10 \mu M$ ATP. Thus, the intracellular ATP concentration was probably considerably greater than $10 \mu M$. Similar effects of $\mathrm{DiC}_{8}$ and TPA were obtained in $1 \mathrm{~m} M \mathrm{MgATP}$. CONT, control. (From Lee and Holz, 1986.) 
It is unlikely that activation of protein kinase $\mathrm{C}$ is obligatory in the secretory pathway in chromaffin cells. Experiments with trypsin in permeabilized cells reveal that the phorbol ester-mediated enhancement of secretion can be inhibited without inhibition of phorbol ester-independent secretion (Holz and Senter, 1988). Thus, it is likely that protein kinase C plays a modulatory, rather than an obligatory, role in secretion induced by nicotinic agonists.

In summary, nicotinic stimulation results in $\mathrm{Ca}^{2+}$ influx. The rise in cytosolic $\mathrm{Ca}^{2+}$ has at least three effects which are important for secretion.

(1) $\mathrm{Ca}^{2+}$ directly activates the secretory pathway through yet unknown mechanisms.

(2) $\mathrm{Ca}^{2+}$ activates phospholipase $\mathrm{C}$ and may generate diglyceride.

(3) $\mathrm{Ca}^{2+}$, perhaps acting together with diglyceride, causes the translocation and activation of protein kinase $\mathrm{C}$. The activation of protein kinase $\mathrm{C}$ enhances $\mathrm{Ca}^{2+}$-dependent secretion.

\section{ACKNOWLEDGMENTS}

This work was supported by PHS Grants R01DK27959 and P01HL18575. R. W. Holz is an Established Investigator of the American Heart Association.

\section{REFERENCES}

Casey, R. P., Njus, D., Radda, G. K., and Sehr, P. a. (1977). Active proton uptake by chromaffin granules: Observation by amine distribution and phosphorus-21 nuclear magnetic resonance techniques. Biochemistry 16:972-977.

Castagna, M., Takai, Y., Kaibuchi, K., Sano, K., Kikkawa, U., and Nishizuka, Y. (1982). Direct activation of calcium-activated phospholipid-dependent protein kinase by tumor-promoting phorbol esters. J. Biol. Chem. 257:7847-7851.

Douglas, W. W. (1975). Secretomotor control on adrenal medullary secretion: Synaptic, membrane and ionic events in stimulus-secretion coupling, In Handbook of Physiology Endocrinology (Blashko, H., Sayer, G., and Smith, A. D., Eds.), American Physiological Society, Washington, D.C., Sect. 7, Vol. 6, pp. 367-388.

Dunn, L. A., and Holz, R. W. (1983). Catecholamine secretion from digitonin-treated adrenalmedullary chromaffin cells. J. Biol. Chem. 258:4989-4993.

Eberhard, D. A., and Holz, R. W. (1987). Cholinergic stimulation of inositol phosphate formation in bovine adrenal chromaffin cells: Distinct nicotonic and muscarinic mechanisms. $J$. Neurochem. 49:1634-1643.

Holz, R. W. (1978). Evidence that catecholamine transport into chromaffin vesicles is coupled to vesicle membrane potential. Proc. Natl. Acad. Sci. USA 75:5190-5194.

Holz, R. W., and Senter, R. A. (1985). Plasma membrane and chromaffin granule characteristics in digitonin-treated chromaffin cells. J. Neurochem. 45:1548-1557.

Holtz, R. W., and Senter, R. A. (1988). Effects of trypsin on secretion stimulated by micromolar $\mathrm{Ca}^{2+}$ and phorbol ester in digitonin permeabilized adrenal chromaffin cells. Cell. Mol. Neurobiol. 8:115-128.

Holz, R. W., Senter, R. A., and Frye, R. A. (1982). Relationship between $\mathrm{Ca}^{++}$uptake and catecholamine secretion in primary dissociated cultures of adrenal medulla. J. Neurochem. 39:635-646.

Holz, R. W., Senter, R. A., and Sharp, R. R. (1983). Evidence that the $\mathrm{H}^{+}$electrochemical gradient 
across membranes of chromaffin granules is not involved in exocytosis. J. Biol. Chem. 258:7506-7513.

Johnson, R. G., and Scarpa, A. (1976). Internal pH of isolated chromaffin vesicles. J. Biol. Chem. 251:2189-2191.

Johnson, R. G., and Scarpa, A. (1979). Protonmotive force and catecholamine transport in isolated chromaffin granules. J. Biol. Chem. 254:3750-3760.

Kikkawa, U., Takai, Y., Minakuchi, R., Inohara, S., and Nishizuka, Y. (1982). Calcium-activated, phospholipid-dependent protein kinase from rat brain. J. Biol. Chem. 257:13341-13348.

Kilpatrick, D. L., Slepetis, R. J., Corcoran, J. J., and Kirshner, N. (1982). Calcium uptake and catecholamine secretion by cultured bovine adrenal medulla cells. J. Neurochem. 38:427-435.

Kishimoto, A., Takai, Y., Mori, T., Kikkawa, U., and Nishizuka, Y. (1980). Calcium and phospholipid-dependent protein kinase $\mathrm{C}$ activation by diacylglycerol, its possible relations to phosphatidylinositol turnover. J. Biol. Chem. 255:2273-2276.

Knight, D. E., and Baker, P. F. (1982). Calcium dependence of catecholamine release from bovine adrenal medullary cells after exposure to intense electric fields. J. Membr. biol. 68:107-140.

Knight, D. E., and Baker, P. F. (1983). The phorbol ester TPA increases the affinity of exocytosis for calcium in "leaky" adrenal medullary cells. FEBS Lett. 160:98-100.

Lee, S. A., and Holz, R. W. (1986). Protein phosphorylation and secretion in digitonin-permeabilized adrenal chromaffin cells: Effects of micromolar $\mathrm{Ca}^{2+}$, phorbol esters and diacylglycerol. $J$. Biol. Chem. 261:17089-17098.

Njus, E., Kelly, P. M., and Harnadek, G. J. (1986). Bioenergetics of secretory vesicles. Biochim. Biophys. Acta 853:237-265.

Pocotte, S. L., Frye, R. A., Senter, R. A., TerBush, D. R., Lee, S. A., and Holz, R. W. (1985). Effects of phorbol ester on catecholamine secretion and protein phsophorylation in adrenal medullary cell cultures. Proc. Natl. Acad. Sci. USA 82:930-934.

Portzehl, H., Caldwell, P. C., and Ruegg, J. C. (1964). The dependence of contraction and relaxation of muscle fibers from the Crab Maia squinado on the internal concentration of free calcium ions. Biochim. Biophys. Acta 79:581-591.

TerBush, D. R., and Holz, R. W. (1986). Effects of phorbol esters, diacylclycerol and cholinergic agonists on the subcellular distribution of protein kinase $\mathrm{C}$ in intact or digitonin-permeabilized adrenal chromaffin cells. J. Biol. Chem. 261:17099-17106.

Viveros, O. H. (1975). Mechanism of secretion of catecholamines from adrenal medulla, In Handbook of Physiology Endocrinology (Blashko, H., Sayer, G., and Smith, A. D., Eds.). American Physiological Society, Washington, D.C. Sect. 7, Vol. 6, pp. 389-426.

Wilson, S. P., and Kirshner, N. (1983). Calcium-evoked secretion from digitonin-permeabilized adrenal medullary chromaffin cells. $J$. Biol. Chem. 258:4994-5000.

Wise, B. C., Raynor, R. L., and Kuo, J. F. (1982). Phospholipid-sensitive $\mathrm{Ca}^{++}$-dependent protein kinase from heart. J. Biol. Chem. 257:8481-8488.

Yamanishi, J., Takai, Y., Kaibuchi, K., Sano, K., Castagna, M., and Nishizuka, Y. (1983). Synergistic functions of phorbol ester and calcium in serotonin release from human platelets. Biochem. Biophys. Res. Commun. 112:778-786. 